\author{
Z. Tatyyeva ${ }^{1}$, A. Zagidullina ${ }^{2}$ \\ ${ }^{1,2}$ Kazakh Ablai Khan University of International Relations and World Languages, \\ Almaty, Kazakhstan
}

\title{
DISCOURSE ANALYSIS OF ORGANIZATIONAL IDENTITY PRESENTED BY PEDAGOGICAL UNIVERSITIES OF KAZAKHSTAN
}

\begin{abstract}
The current study is about the discourse analysis of Kazakhstani pedagogical universities identity presented in the official websites of the universities. Latest educational reforms made pedagogical universities to reconsider their identity to be sure that they are following the trend. This research attempts to understand what pedagogical universities are, how they are transforming through the discourse they created in their websites. 7 specialized and biggest pedagogical universities in Kazakhstan were chosen to investigate. The results of the study showed that universities are tent to prescribe the best qualities by marking themselves using strong adjectives and strong nominalization. Another commonality among universities was that all of them show clear difference between classical education and modern educational development and they want to take both of them.
\end{abstract}

Key words: discourse,pedagogical universities, organizational identity, discourse analysis

$$
\text { Ж. } \text { Татыева }^{1} \text {, А. Загидуллина }{ }^{2}
$$

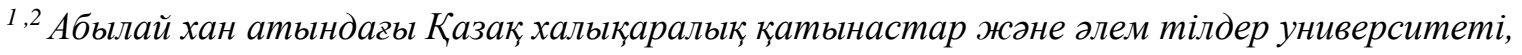
Алматы қ., Қазақстан

\section{ҚАЗАҚСТАННЫҢ ПЕДАГОГИКАЛЫҚ УНИВЕРСИТЕТТЕРІНІҢ ҰЙЫМДЫҚ ӨЗГЕШЕЛІКТЕРІН ДИСКУРС ТАЛДАУ}

\section{Аңъдатпа}

Бұл зерттеу қазақстандық педагогикалық жоғары оқу орындарының ресми сайттарында ұсынылған "Университеттуралы" бөлімініңдискурстық талдауы болып табылады. Соңғы уақытта орын алған білім реформаларына байланысты педагогикалық университеттер өзгерістерге сай болу үшін өзіндік ұйымдық ерекшеліктерін қайта сипаттап жазуға мәжбүр болды. Бұл зерттеу педагогикалық университеттердіңұйымдық ерекешліктерін, олардың веб-сайттарында жариялаған мәтіндік ақпарат негізінде дискурс талдау жасайды. Зерттеу барысында Қазақстандағы 7 мамандандырылған, ірі педагогикалық университеттер талданды. Зерттеу нәтижелері көрсеткендей, жоғары оку орындары өзіндік ерекшеліктерін көрсету үшін көп сын есімдер пайдаланады, жәнесын есімдердің номинациялануыкең қолданылады, бұл ұйымдардың ең жақсы қасиеттерді айқындап көрсетуіне себепкер болады. Университеттер арасында тағы бір ортақ нәрсе, олардың барлығы классикалық білім мен қазіргі білім беру жүйесінің арасындағы айқын айырмашылықтарды айқындап, екеуін де қабылдауға ұмтылатындарын көрсеткен.

Түйін сөздер: дискурс, педагогикалық университеттер, ұйымдық өзгешелік, дискурс талдау

$$
\text { Ж. Татыева }{ }^{1} \text {, А.Загидуллина }{ }^{2}
$$

${ }^{1,2}$ Казахстанский университет международных отношении и мировых языков, им. Абылай хана Алматы, Казахстан

\section{ДИСКУРС АНАЛИЗ ОРГАНИЗАЦИОННОЙ ИДЕНТИЧНОСТИ ПРЕДСТАВЛЕННОГО ПЕДАГОГИЧЕСКИМИ ВУЗАМИ КАЗАХСТАНА}


Данное исследование является дискурс анализом идентичности казахстанских педагогических вузов, представленный на официальных сайтах вузов. Последние образовательные реформы заставили педагогические университеты пересмотреть свою идентичность, чтобы быть уверенными, что они следуют этой тенденции. Это исследование пытается понять, что из себя представляют педагогические университеты, как они трансформируются через дискурс, который они создали на своих сайтах. 7 специализированных и крупнейших педагогических вузов Казахстана были выбраны для исследования. Результаты исследования показали, что университеты стремятся писать о своихлучших качествах, отмечая себя убедительными прилагательными и используя способы номинализаций. Еще одна общая черта университетов заключалась в том, что все они разграничивают классическое (т.е. советское) образование и современное образование, и они хотят принять оба типа образования.

Ключевые слова: дискурс, педагогические вузы, организационная идентичность, дискурсанализ

Introduction.Education in Kazakhstan has become a landscape for changes, reforms and experiments in last decades, e.g., introducing a new, updated curriculum for secondary schools (2006), launching new typed schools (like Nazarbayev Intellectual Schools), giving academic freedom to universities (2018) and introducing the Law on Teachers' Status (2019). All these changes are believed to bring innovations and boost development of human capital in Kazakhstan and the country in general. As all reforms touch upon educationalists who mainly graduate from pedagogical universities, it is better to start understanding the general development of education system of Kazakhstan by creating the vision of pedagogical universities. The identity of Kazakhstani pedagogical universities is essential to consider as it impacts on teachers' identity.

The formation of teachers' identity, as any other individual's identity, is a complex process. Answer to this question may not be covered from only one perspective. To trace the identity formation multiple viewed analysis should take place. According to Gee [1] there are four ways to view identity: Natureidentity, Institution-identity, Discourse-identity, and Affinity-identity. This study explores one aspect that may affect to teachers' identity, which is Institution identity. Identity can be developed within an institution, laws, traditions, principles, culture of an organization empower a person to create certain characteristics and skills that become part of individual's identity [1, 102]. No matter what influenced on creating the particular type of identity text, universities self-presentation is considered as a strategic communication, i.e. the way how universities want to be perceived [2]. The aim of the research is to explore organizational identity of Kazakhstani pedagogical universities. The study hopes to investigate the institutional identity of teachers in the context of Kazakhstani higher educational organizations.

There are many studies that explore higher education organization's identity from different perspectives from all parts of the world. There are American studies, e.g.Hartley and Morphew [3] in 2008 analysed the promotional booklets of US colleges. The study highlights the controversy of universities self-presentation. If one side they want to stand out and show off their uniqueness, on other hand they tend to look similar and use clichéd description. This probably because of competitiveness among universities, as it was revealed by Gioia and Thomas [4] in their study of top 10 universities.European universities were also widely analysed, e.g. 17 Sweedish universities were compared by Opoku, Hultman, and Saheli-Sangari[5], where distinctive difference between universities were found. If some educational organizational tried to present their brand clearly in and in a more complicated way, while other half of universities did not and made their brand image obscure. Sauntsonand Morrish[6] in a conclusion of their comparative study of50 UK universities mission statements found out the tendency of universities to standardize their statements. The case study of Norwegian university conducted byStensaker and Norgard [7] showed the transformation taking place in the educational organizations can also be reflected in a mission statements of the universities. Another transformational challengeis facing the old European universities[8] in way of being idiosyncratic and to fit local standards of higher educational organizations.Huseinman and Mampaey[9] after analyzing 29 universities came to the conclusion that most of the universities share the same description of organization identity. However, the later established universities make some attempts to distinct from others.

Johnson [10] in his study analysed the teacher's identity by using elements of ethnomethodological and conversational analysis research methods. The interview with a teacher asking a critical reflection of the teacher allowed to describe the teacher's identity. The study analysed the identity from two different perspectives. "Top-down" approach is based on the assumption that all the speech produced by a person 
is a reflection of an ideology and society he or she surrounded by [11]. While "bottom-up" approach focus on a personal trait of interviewee and it gives some clue on what are the people she or he is surrounded by. The study reviled the dilemma teachers are always facing. From wider perspective on the one hand, it is the external impact, i.e. the requirement of high standards that government, or/and educational organizations, parents impose, one the other hand the actual abilities and motivation of students. These two controverting make teaching process highly stressful. The interviewed teacher mentioned that " "parental expectations of excellence" generated from "the materialistic world that we live in" and "a parental value-for-money mentality" " $[11,221]$. Concerning the personal identity interviewee merged an institutional teacher identity with personal identity. Later with the help of researched she was able to give more personalized information on identity. This might be an example of influence of institutional identity towards personal, how personal professional identity can be embed with institutional one.

Analyzed literature review showed the intertwined link between organizational identity, professional identity and personal identity. These terms cannot be considered separately, which add up value to the current study. Another rational for study is lack of specialized discourse analysis. Most of the studies are about general organizational or universities identities, while only a few study touches upon specialized universities. One more to mention is scarcity of scholarly articles on Kazakhstani universities, all mentioned above can be a grounding to do a research.

Methods.The study used discourse analysis and context analysis of missions and strategic goals of 7 biggest and specialized pedagogical universities of Kazakhstan. The official mission and vision statements of the universities, posted on the official websites, are compiled together after discourse and content analyses were conducted. The analysed universities are Kazakh National Pedagogical university named after Abai, Kazakh State Women's Pedagogical University, Kostanay State Pedagogical University, Pavlodar State Pedagogical University, Tazar State Pedagogical University, Arkalyk State Pedagogical University named after Altynsaryn, South Kazakhstan State Pedagogical University. Overall among all 7 universities collected and analysed about 300 words of organizational identity texts and about 250 words of envisioned graduates, i.e. future teachers' identity.

The study used the discourse analysis (DA). The discourse analysis is identified by van Dijk and Kintch[12] as a way of exploring the social word in the context of discourse. 'The self no longer uses language to express itself; rather language speaks through the person. The individual self becomes a medium for the culture and its language' $[12,36]$. In the context of current study, the method is used to discover the created society through the text. As the aim of the study is to explore the identity of pedagogical universities and the identity of teachers, that universities are to foster, the approach of Laclau and Mouffle is found to be the most suitable to use. Key frameworks of this approach are identity is created within discourse; identity is constructed relatively to something else, and it is constant in a change as well as discourse. This approach includes the exploratory means of social actors (universities and teachers) description. First, the linguistic analysis of the textis used on the micro level and after due to its effectiveness to construct the Kazakhstani pedagogical universities identity.

The analytical framework was based on Koller's [12] a three-step analysis modelof the following mode:

- who is implicitly or explicitly present, or absent altogether;

- how those present are referred to: as active or passive, more or less agentive, and in personal or impersonal ways; and

- what relationship between communicator, audience, and third parties is constructed?

First step requires identification of social actors in the text. It means the text is analyzed for presence or absence of social actors, and if their presence is overt or obscure. Impersonalization is one of the ways how to exclude social actors from the text, which is achieved by a nominalization and an objectivation. Nominalization means different parts of speech, e.g. verbs, adjectives are turned into noun, while objectivation is achieved by using a linguistic device - metonymy. Next step is to explore active or passive presence of social actors. The use of passive and active tenses in the text, and the level of agentive usage and in personal and impersonal approaches are going to analyzed. The third action is to explore the link among communicator, audience and third parties. This framework is believed to help to reveal the discourse created by Kazakhstani pedagogical universities.

Results.Analyzed mission statements showed the most frequently mentioned phrases (4-5 times) in mission statements are 'competitive', 'educational', 'pedagogical', 'professional', 'innovative', 'pedagogical elite of 21 century' (конкурентоспособный, образовательный, педагогический, профессиональный, инновационный, хx1 века, педагогическойэлиты). There are several concepts are 
developed: one is expected "teachers' identity", i.e. what kind of qualities are expected from graduates; next is the "university's self-vision", i.e. how the university portraits itself, another nodal concept is "education".

Teachersidentity is presented by words like professionals, competent, competitive, highly qualified cadres, who impact economic development of a country and enrich human resource. The following concepts: Prestigious and Elite are still present, although considerably weak, mentioned only by couple of universities. The more detailed description is given to the competences that teachers should possess:'multilingual', 'can work in ungraded schools', 'have competences aligned with demands of society and working force', 'obtained fundamental knowledge and innovative approaches', 'patriotic'.

Organizational identityof pedagogical universities is highlightedby their idiosyncratic peculiarities by mentioning that they are pedagogical university and educational organization. Another group of adjectives likeleader,dominant, prestigious, the best pedagogical universityadd up additional featuresto the universities how they envision themselves. It is expected in representative texts each university position itself as the bestone. Next group of words economics related concepts: innovative, competitive, country's economics driver, contribute to country economic development. These words show another role that universities take as a duty, responsibility to economic development of a country. It is worth to mention that all 7 universities are considered as State universities, as in their name all of them have either "National" or "State" status. It was interesting to note that he universities give clear distinction between classical education and modern educational development. This trend was noted in the most of analysed universities by phrases like "combination of classical education and newest educational technologies", "combining long-standing traditions and modern technologies in the field of education", "implementing traditional and modern teaching technologies". Impersonalization is achieved by nominalization of adjectives into nouns and adding calling phrases like "the best", "the elite", "leader" and "dominant". No objectivation is used, as any metonyms were not found.

Discussion. There are multiple approaches on understanding what the institutional identity is, and how to identify it, due to the term ambiguity. There are four paradigms on how organizational identity might be defined [13]. The functional paradigm states the organizational identity as set of core 'rules' that members of the organization must follow strictly [14;20]. It leads to the vision that standards and culture of organization shape and impact to people who are involved in this organization. Next social construction perspective claim that identity is constructed both by the internal members and by the external members, what the identity we accept as the organizational identity is created and depended on involved people. The postmodernism perspective of organizational identity view it as politically assigned vision to the organization by a country, that might be controversial on its members opinion [15]. The last according to psychodynamics perspective unconscious emotions act as individuals' defence can be adjusting collective self-esteem that form organizational identity [16]. The study is based on the functional paradigm towards identity, the mission statement of the university is assumed to be the vision what the university see itself and strive for to be.

Discourse analysis and content analysis helped to analyse the written mission statement of pedagogical universities and for more deep analysis and for revealing more aspects of universities intention of realisation of stated mission further research is needed. There are several key concepts, which define teachers' identity. Teachers, i.e. future graduates of the pedagogical universities are to be professional and elite in order to contribute economic development of the country. Here, even though we look at 'functional role' of identity, the post modernistic view assuming the influence of country's political vision is important to mention[15]. The latest reforms taking place in education clearly make impact on what pedagogical universities envision. This probably occurs because all universities are under the governance of state and the pedagogical universities are viewed more like realisers of political policies. It is interesting to note that there is no private pedagogical university in Kazakhstan. Worth to mention that expected qualities from graduates are aligned with local demand, which make the universities unique.

Qualities prescribed to universities are aligned with expected graduates' qualities. There are similarities in features like prestigious, contributing to economic growth. Quite distinctive feature in organizational identity description is added information on teaching methods. Here, one common trend among most of the universities is "combination of traditional methods of teaching with innovative ones". This somehow reflect the idea that universities still differentiate the Soviet Union period teaching method and post-Soviet teaching method, and educational organizations try to see them separately.

Social identity theory states interlink between personal identity and organizational identity. Therefore, these two concepts should be analysed together, as there is undeniable role of professional 
identity to form organizational one. As a process of self-identification refers to self-perception, it goes without saying, professional life of a person is merged with values and attributes of an organization. The more active organization promote and socialize its identity the deeper influence it makes to the stuff. The analyzed Institutional-identity perspective helped to expand the notion of professional teacher identity.

Conclusion. The study was aimed to identity the organizational identity of pedagogical universities in Kazakhstan. During the study 7 Kazakhstani pedagogical universities mission statements were analyzed. According to the functional paradigm the organizational identity is the way how universities see themselves and what they want to be. The researching subjects are educational organizations universities, and educational organizations also may present their organizational identity in terms of graduates they are aimed to foster, therefore the two domains of identity were included into analysis: one is anticipated characteristics of graduates, and the second is description of the university itself. The results showed the alignment of teachers' identity and universities' identity depictions. 3 common key characteristics were identified: professionalism, prestige, and ability to contribute to country's economics. Even though the functional paradigm was used to analyze, it was obvious that the post-modernistic view on identity should betaken into account, which emphasizes the role of politics in creating identity of the organization. Kazakhstani pedagogical universities are aimed to work for internal economy and raise the status of pedagogical specialties. Another finding was that some universities distinguish teaching methods into traditional and innovative, that universities want to implement new teaching approaches keeping the conventional ones. For further research, it would be interesting to conduct comparative analysis of pedagogical universities with other types of universities, and to do cross-cultural analysis among Kazakhstani universities with international ones.

References:

1) Gee, P. J. Identity as an Analytic Lens for Research in Education. // Review of Research in Education - №25 -2000, pp. 99-125. URL: http://www.jstor.org/stable/1167322--journal article.

2) Gioia, D. A., Schultz, M., Corley, K. G. Organizational identity, image, and adaptive instability.// Academy of Management Review- 2000-№25-pp. 63-81. - journal article

3) Hartley, M., Morphew, C. C. What's being sold and to what end? A content analysis of college viewbooks. //Journal of Higher Education- №79 - p. 671-691. - journal article

4) Gioia, D. A., Thomas, J. B. Identity, image and issue interpretation: Sensemaking during strategic change in academia // Administrative Science Quarterly. -1996 - №41 -pp.370-403. - journal article

5) Opoku, R. A., Hultman, M., Saheli-Sangari, E. Positioning in market space: The evaluation of Swedish universities' online brand personalities. //Journal of Marketing in Higher Education. - 2008№18- pp. 124-144. - journal article

6) Sauntson, H., Morrish, L. Vision, values and international excellence: The products that university mission statements sell to students. In M. Molesworth, E. Nixon, \& R. Scullion (Eds.), The marketisation of UK higher education and the student as consumer. London: Routledge.- 2010- pp. 7385. - journal article

7) Stensaker, B., Norgård, J. N. Innovation and isomorphism: A case-study of university identity struggle 1969-1999.// Higher Education.- 2001- №42-pp. 473-492. - journal article

8) Huisman, J., Norgård, J. N., Rasmussen, J. G., Stensaker, B. 'Alternative' universities revisited: A study of the distinctiveness of universities established in the spirit of 1968. I/Tertiary Education and Management,- 2002-№8- pp.315-332. - journal article

9) Johnson, G. C. Chapter 8. The discursive construction of teacher identities in a research interview// Discourse and identity. Edited by Anna de Fina, Deborah Schiffrin, Michael Bamberg. - 2009 -URL:https://doi.org/10.1017/CBO9780511584459.011 - journal article

10) Davies, B., Harré, R. Positioning: The discursive production of selves// Journal for the theory of social behavior. -№20 (1)-1990, p.43-63. - journal article

11) Gee, J. P. Social linguistics and literacies: Ideology in discourses (2nd ed.). London: Taylor\&Francis, London - 1996.- textbook

12) Koller, V. Analyzing collective identity in discourse: social actors and contexts // SEMEN: Revue de semoi-linguistique des textes et discours. - 2009 - journal article

13) Mujib, H. Organizational Identity: An Ambiguous Concept in Practical Terms. //Administrative Sciences - 2017- №28 (7). doi:10.3390/admsci7030028 - journal article

14) Gioia, D. A. From Individual to Organizational Identity. // Identity in Organizations Building Theory Through, Conversations. Edited by David A. Whetten and Paul C. Godfrey. Thousand Oaks: Sage Publications. - 1998. - pp. 17-31. - book 
15) Cooper, R., Burrell, G. Modernism, postmodernism and organizational analysis: An introduction// Organization Studies. -1988. - №9. - p.91-112. - journal article

16) Brown, A.D., Starkey, K. "Organizational identity and learning: A psychodynamic perspective"//Academy of Management Review, -2000. - №25. -p.102-20. - journal article 